\title{
PERAMALAN JUMLAH PEMASANGAN WIFI INDIHOME DI PT.TELEKOMUNIKASI KANDATEL LANGSA
}

\author{
Riska Novita Sari ${ }^{1}$, Riezky Purnama Sari ${ }^{2}$ \\ 1,2Universitas Samudra; Jln.Meurandeh,Kota Langsa,24415 \\ Jurusan Matematika, Fakultas Teknik, Universitas Samudra \\ email :1novitar04@gmail.com, 2riezkypurnamasari@gmail.com
}

\begin{abstract}
ABSTRAK
Peramalan merupakan dugaan terhadap permintaan yang akan datang berdasarkan pada beberapa variabel peramal, sering berdasarkan data deret waktu historis. Untuk peramalan penulis menggunakan metode Regresi linear sederhana dengan Rumus $\mathrm{Y}=\mathrm{a}+\mathrm{bX}$. Analisa regresi linear sederhana merupakan salah satu metode uji regresi yang dapat dipakai sebagai alat inferensi statistik untuk menentukan pengaruh sebuah variabel bebas ( independen ) terhadap variabel terikat ( dependen ). Pada analisa regresi sederhana dengan menggunakan SPSS ada beberapa asumsi dan persyaratan yang perlu diperiksa dan diuji, model regresi dinyatakan layak jika angka signifikan pada ANOVA sebesar $<0.05$, prediktor yang digunakan sebagai variabel bebas harus layak. Kelayakan ini diketahui jika angka Standard Error of Estimasi < Standard Deviation. Berdasarkan hasil perhitungan output SPSS 20 bahwa pesamaan garis regresi dapat di rumuskan sebagai berikut $\mathrm{Y}=638.848-10.182 \mathrm{X}$. Peramalan pemasangan wifi ini bertujuan untuk memperkirakan apa yang terjadi di masa yang akan datang, dan melihat situasi dan kondisi yang terjadi, dengan memperkirakan dari 12 bulan yang lalu. Dari pengolahan peramalan data pemasangan wifi dengan metode analisis regresi sederhana menggunakan perangkat lunak SPSS 20 menghasilkan kenaikkan pemasangan wifi pada bulan Januari 2021 dan mengalami penurunan terusmenerus pada bulan Februari 2021 hingga Desember 2021.
\end{abstract}

Kata Kunci : Peramalan, Regresi Linear Sederhana, Jumlah Pemasangan Wifi, SPSS 20

\begin{abstract}
Forecasting is an estimate of future demand based on several forecasting variables, often based on historical time series data. For forecasting the author uses a simple linear regression method with the formula $\mathrm{Y}=\mathrm{a}+\mathrm{bX}$. Simple linear regression analysis is a regression test method that can be used as a statistical inference tool to determine the effect of an independent (independent) variable on the dependent (dependent) variable. In simple regression analysis using SPSS there are several assumptions and requirements that need to be checked and tested, the regression model is declared feasible if the significant number on the ANOVA is $<0.05$, the predictor used as the independent variable must be feasible. This feasibility is known if the number of Standard Error of Estimation < Standard Deviation . Based on the results of SPSS 20 output calculation that the equation of the regression line can be formulated as follows $\mathrm{Y}=638.848-10.182 \mathrm{X}$. Forecasting this wifi installation aims to predict what will happen in the future, and see the situation and conditions that occur, by estimating from 12 months ago. From the processing of forecasting wifi installation data with a simple regression analysis method using SPSS 20 software, it resulted in an increase in wifi installation in January 2021 and a continuous decline in February 2021 to December 2021.
\end{abstract}

Keywords: Forecasting, Simple Linear Regression, Number of Wifi Installations, SPSS 20

\section{PENDAHULUAN}

Peramalan adalah suatu hal yang sangat penting dalam era modern saat ini, khususnya dalam mengambil sebuah keputusan (Awat, 1990). Peramalan adalah kegiatan memperkirakan tingkat permintaan produk yang diharapkan untuk suatu produk atau beberapa produk dalam periode waktu tertentu di masa yang akan datang (Biegel, 1999).

Demi untuk memiliki suatu keunikan tersendiri yang dapat memikat konsumen dalam rangakaian mempertahankan atau merebut pangsa pasar yang ada, maka PT. Telkom Tbk khususnya PT. Telkom Langsa meluncurkan IndiHome merupakan bundling dari produk-produk Telkom yang menyediakan layanan telepon rumah, akses internet berkecepatan tinggi, layanan tv interaktif sekaligus dengan berbagai konten seperti layanan portal music digital dan home automation kepada pelanggan dan juga harga paket sesuai kebutuhan 
paket yang digunakan oleh pelanggan.

IndiHome merupakan layanan Triple Play dari Telkom yang terdiri dari internet on Fiber atau High Speed Internet, Phone (Telepon Rumah), dan IPTV (useTV Cable). IndiHome merupakan produk baru dari PT. Telkom Tbk Langsa yang dikeluarkan pada awal tahun 2015. Strategi penerapan promosi pada indihome sangat penting dalam usaha untuk memperkenalkan produk terbaru yang di keluarkan oleh PT. Telekomunikasi Indonesia khususnya wilayah Langsa.

Oleh karena itu, peramalan jumlah pemasangan indihome ini bertujuan untuk mengetahui jumlah pemasangan yang akan datang, PT. Telekomunikasi Kandatel Langsa menggunakan peramalan dengan metode Regrensi Linier Sederhana yang dibantu aplikasi SPSS 20 dengan sistem variabel peramalan berdasarkan data deret waktu historis yang diharapkan dapat meningkatkan layanan sesuai kebutuhan dan mengetahui jumlah pemasangan yang akan datang.

Tujuan dari penulisan ini adalah Untuk mengetahui bagaimana sistematik cara peramalan jumlah pemasangan indihome di PT. Telekomunikasi Kandatel langsa dengan metode Regresi Linear Sederhana dan Untuk mengetahui hasil peramalan atau prediksi 12 bulan yang akan mendatang.

\section{METODOLOGI PENELITIAN}

Data yang digunakan pada penelitian ini yaitu data sekunder yang diperoleh dari sumber yang sudah ada di kantor PT. Telekomunikasi Kandatel Langsa. Adapun data yang digunakan dalam penelitian ini adalah data kuantitatif yaitu jenis data yang dinyatakan dengan bilangan atau angka dan dapat diukur atau dihitung secara langsung. Dalam hal ini data kuantitatif yang diperlukan adalah Jumlah Pemasangan WiFi. Penulisan ini menggunakan 2 macam variabel, yaitu Variabel Independen $(Y)$ dan variabel Independen $(X)$.

Tabel data pemasangan wifi indihome

Tabel 1. Data Jumlah Pemasangan WiFi Indihome

\begin{tabular}{lcc}
\hline \multicolumn{1}{c}{ Bulan } & X & Y \\
\hline Januari 2020 & 1 & 506 \\
Februari 2020 & 2 & 406 \\
Maret 2020 & 3 & 567 \\
April 2020 & 4 & 949 \\
Mei 2020 & 5 & 573 \\
Juni 2020 & 6 & 684 \\
Juli 2020 & 7 & 706 \\
Agustus 2020 & 8 & 579 \\
September 2020 & 9 & 523 \\
Oktober 2020 & 10 & 474 \\
November 2020 & 11 & 453 \\
Desember 2020 & 12 & 452 \\
\hline
\end{tabular}

Sumber : PT. Telekomunikasi Kandatel Langsa 2020

Dalam melakukan analisis data, ada dua tahap yang akan dilakukan yaitu :

Tahap 1 : Menghitung Statistik Deskriptif

Untuk menggambarkan kondisi deskriptif variabel yang ada digunakan tabel distribusi frekuensi absolut yaang menunjukkan jumlah data $(\mathrm{N})$, nilai minimum, nilai maksimum, rata - rata hitung (mean), dan deviasi standar (standard devation).

Tahap 2 : Uji Normalitas, Multikolinearitas,

Heteroskedastisitas, dan Autokorelasi.

Sebelum melakukan analisis regrensi sederhana maka terlebih dahulu dilakukan pengujian asumsi klasik. Pengujian asusmsi klasik yang akan digunakan dalam penelitian ini meliputi uji normalitas, multikolinearitas, heteroskedastisitas, dan uji autokorelasi.

\section{Regrensi Linear Sederhana}

Setelah dilakukan pengujian terhadap uji asumsi klasik (normalitas, multikolinearitas, heteroskedastisitas, dan autokorelasi) diatas, maka langkah selanjutnya yaitu mencari persamaaan linearnya. Analisis regresi merupakan suatu analisis yang sering digunakan dalam mengukur seberapa besar pengaruh variabel independen terhadap variabel dependen. Adapun metode analisis yang digunakan adalah metode analisis regrensi linear sederhana karena varibel independen dalam penelitian ini hanya satu variabel. Model matematis dari analisis regresi linier sederhana adalah :

$$
Y=a+b X
$$

Dimana :

$\mathrm{Y}=$ Variabel Jumlah Pemasangan WiFi Indihome $\mathrm{X}=$ Variabel bulan

\section{Peramalan}

Tahap terakhir pada metode regresi linear sederhana yaitu melakukan peramalan (forecasting). Peramalan ini dilakukan untuk mengetahui Jumlah Pemasangan WiFi Indihome untuk 12 bulan kedepan.

\section{HASIL DAN PEMBAHASAN}

3.1 Descriptive Statistics

Tabel 2. Statistik Deskriptif

\begin{tabular}{lccccc}
\multicolumn{6}{c}{ Descriptive Statistics } \\
\hline N & Min & Max & Mean & $\begin{array}{c}\text { Std. } \\
\text { deviation }\end{array}$ \\
\hline $\begin{array}{l}\text { Jumlah } \\
\text { pemasangan } \\
\text { Valid N } \\
\text { (listwise) }\end{array}$ & 12 & 406 & 949 & 572,67 & 149,294 \\
\hline
\end{tabular}

Berdasarkan angka yang diperoleh pada tabel Descriptive Statistics :

a. $\quad \mathrm{N}=12$ artinya periode waktu yang digunakan adalah 12 bulan yaitu Januari 2020, Februari 2020, Maret 2020, April 2020, Juni 2020, Juli 2020, Agustus 2020, September 2020, Oktober 2020, November 2020, dan Desember 2020.

b. Minimum $=406$ menunjukkan bahwa tingkat Jumlah Pemasangan WiFi Indihome di Kandatel Langsa terendah dalam periode bulan Januari 2020 - Desember 2020 adalah 406

c. Maximum $=949$ menunjukkan bahwa tingkat Jumlah Pemasangan WiFi Indihome di Kandatel Langsa tertinggi dalam periode bulan Januari 2020 - Desember 2020 adalah 949 
c. Standard Error Estimate (SEE) adalah 151,773 artinya perkiraan terhadap kesalahan standar yang bisa terjadi terhadap tingkat Jumlah Pemasangan WiFi di Kandatel Langsa.

\subsubsection{Anova}

Tabel 7. Anova

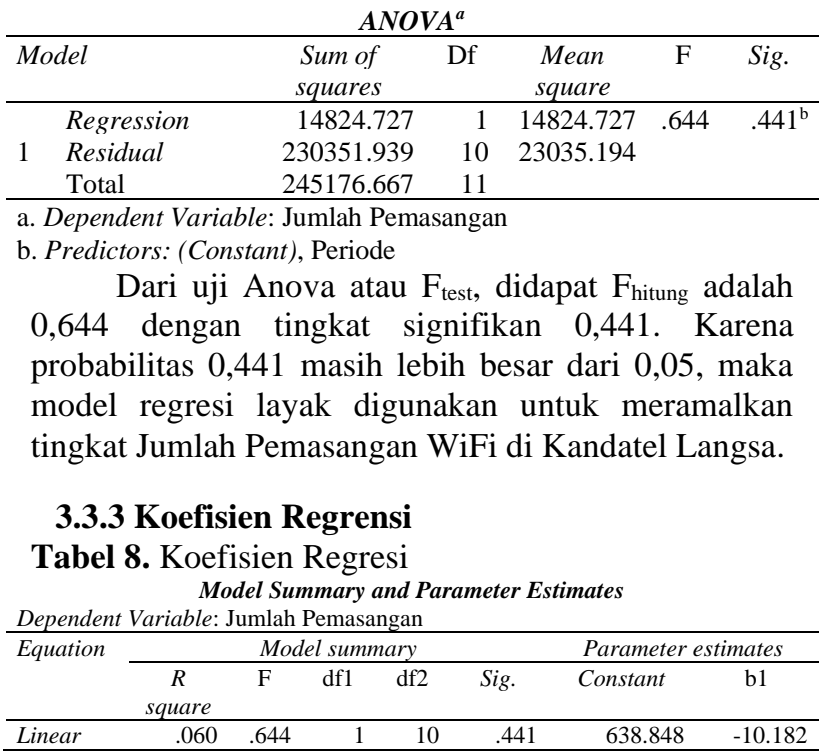

Berdasarkan hasil perhitungan output SPSS

20 bahwa persamaan garis regresi dapat dirumuskan sebagai berikut :

$$
Y=638.848-10.182 X
$$

\subsection{Peramalan}

Tabel 9. Hasil Uji SPSS 20 Peramalan Jumlah Pemasangan WiFi Indihome selama 12 bulan

$$
\text { Jumlah }
$$

Bulan pemasangan wifi indihome

\begin{tabular}{ll}
\hline Januari 2021 & 506 \\
Februari 2021 & 496 \\
Maret 2021 & 486 \\
April 2021 & 476 \\
Mei 2021 & 466 \\
Juni 2021 & 456 \\
Juli 2021 & 445 \\
Agustus 2021 & 435 \\
September 2021 & 425 \\
Oktober 2021 & 415 \\
November 2021 & 405 \\
Desember 2021 & 394 \\
\hline
\end{tabular}

\section{KESIMPULAN DAN SARAN}

\section{Kesimpulan}

Berdasarkan hasil uji persamaan Regresi yaitu $Y=638.848-10.182 X$ diperoleh hasil peramalan Jumlah Pemasangan WiFi Indihome di Kandatel Langsa pada bulan Januari 2021 sebesar 506 Pelanggan, bulan Februari 2021 sebesar 496 Pelanggan, bulan Maret 2021 sebesar 486 Pelanggan, bulan April 2021 sebesar 476 Pelanggan, bulan Mei 2021 sebesar 466 Pelanggan, bulan Juni 2021 sebesar 456 Pelanggan, bulan Juli 2021 sebesar 445 Pelanggan, bulan Agustus 2021 sebesar 435 Pelanggan, bulan September 2021 sebesar 425 Pelanggan, bulan Oktober 2021 sebesar 415
Pelanggan, bulan November 2021 sebesar 405 Pelanggan, bulan Desember 2021 sebesar 394 Pelanggan.

\section{Saran}

Saran untuk penelitian lebih lanjut dapat ditambahkan dengan metode peramalan yang lain seperti Single Eksponensial Smooting, Double Eksponensial Smothing, dan yang lainnya.

\section{UCAPAN TERIMAKASIH}

Puji syukur penulis panjatkan atas kehadirat Allah SWT yang telah melimpahkan rahmat, taufik serta hidaya-Nya sehingga penulis dapat menyelesaikan penelitian tepat waktu dan tanpa adanya kendala yang berarti. Ucapan Terimakasih penulis kepada Ibu kepada Ibu Riezky Purnama Sari selaku dosen pembimbing telah membimbing penulis dalam penelitian ini.

\section{DAFTAR PUSTAKA}

Dyah Nirmala Arun Janie, S.E., M.Si, 2012. Statistik Deskriptif \& Regresi Linier Berganda dengan SPSS. Semarang University Press, ISBN : 978-602-901998-8.

Fathkul Hani Rumawan, Muslimin, Ibon Ba'ba'. 2019. Peramalan Kebutuhan Daya Listrik Jangka Panjang Menengah (2019 - 2022) Kota Samarinda dengan Metode Regresi Linear, Universitas Mulawarman p ISSN : 2598 - 7410, e - ISSN : 2598 7429, 2019.

Hermanto K, Rizqika F. 2019. Metode Regresi yang Tepat untuk Meramalkan Permintaaan Minyak Solar di Kabupaten Sumbawa. Jurnal UJMC, Vol.5 N0.1 Hal : 17-24.

Hikmah khairani. 2016. Analisa Peramalan Jumlah Penduduk Kabupaten PakPak Bharat pada tahun 2017 Menggunakan Metode Regresi. Majalah Ilmiah Informasi dan teknologi Ilmiah. Vol.4 No.1, ISSN : 2339 - 210X

Ir. M. Iqbal Hasan 1999, Regresi Linier Sederhana, Penerbit Andi, Yogyakarta, 2005.

Ida Ayu, Wayan, dan Ratna. 2017. Peramalan Volume Penjualan Buah Jambu Biji Merah (Psidium Guajava Linn) di CV Moena Abadi Sejahtera 1. E-Jurnal Agribisnis dan Agrowisata. Vol. 6 No.2, ISSN : 2301-6523

Makridakis, Syrus. 1993. Metode dan Aplikasi Peramalan. Jakarta: Penerbit Erlangga.

Purwanto H. 2020. Analisis Kepuasan Penumpang terhadap Layanan Free Wifi di Terminal 
Bandara Udara XYZ dengan menggunakan Regresi Linier dan SPSS. JSI (Jurnal Sistem Informasi). Universitas Suryadarma 7(1), 109-136.

Rizky Primadita Ayuwardani, Isroah, M.Si. 2018. Pengaruh Informasi Keuangan dan Non Keuangan Terhadap Terhadap Underpricing Harga Saham pada Perusahaan yang Melakukan Initial Public. Universitas Negeri Yogyakarta. Jurnal Nominal Vol.7 No.1. 2017.

Sulistyono, Sulistiyowati. 2017. Peramalan Produksi dengan Metode Regresi Linier Berganda. Prozima. Vol.1 N0.2, E-ISSN: 2541-5115

Oktariani, Sopian Soim, Adewasti. 2017. Peramalan Pengguna Indihome di PT. Telekomunikasi Tbk Palembang, Universitas Kudus. Prosiding SNATIF KE-14 Tahun 2017, ISBN : $978-602-1180-50-1$ Universitas Kudus.

Wiyono, Joko, siregar, Ninny \& Banjarnahor. M (2018), Peramalan Tingkat Permintaan LPG PT. Pertamina (Persero) di Elpiji Tandem, JIME ( Journal of Industrial and Manufacture Engineering ), 2(2) : 35 - 40. 
